\title{
Study Publication Date
}

National Cancer Institute

\section{Source}

National Cancer Institute. Study Publication Date. NCI Thesaurus. Code C142711.

The date of pubication of an abstract or article pertaining to a particular clinical study. 